\title{
ZAPAŽANJA O OPKORAČENJU U SPISIMA O STIHU SVETOZARA PETROVIĆA*
}

Rad ukazuje na mnoštvo zapažanja i raznih gledišta o anžambmanu u Petrovićevim spisima o stihu, koja se u potonjoj prepisci sa inostranim kolegom nadograđuju, omogućavajući kompletnu karakterizaciju ovog teorijskog pojma. O opkoračenju kao pesničkom postupku pisao je Petrović u više navrata; izdvajaju se segmenti različitih radova kojima se argumentuje književnoistorijska situacija i efekti semantika stiha, kao i dva celovita rada posvećena problematici opkoračenja. Ističe se temeljno definisanje pojma u odnosu na postojeće definicije, razlika između uobičajenog smisla (prihvatljivog u praktičnoj primeni većini onih koji se bave pesništvom) i proširenog obima pojma, kao i polemika sa dosadašnjim shvatanjima i tumačenjima, posebno, s jedne strane, po pitanju preciziranja istorijskog razvoja, a s druge strane, po pitanju prisustva opkoračenja u usmenom narodnom stihu.

Ključne reči: Svetozar Petrović, opkoračenje, sintaksička i metrička segmentacija, Peri i Lord, semantički efekti stiha, usmeni narodni stih.

\section{UVOD}

Mogućnost uvida u neobjavljenu bogatu prepisku akademika Svetozara Petrovića sa jednim profesorom Univerziteta u Viskonsinu, Džejmsom Bejlijem (James Bailey), ${ }^{1}$ fundiranu gotovo u celini na metričkim pitanjima, inicirala je

\footnotetext{
*sanja.paripovic@ff.uns.ac.rs

** Rad je nastao u okviru projekta Aspekti identiteta $i$ njihovo oblikovanje u srpskoj književnosti (broj 178005), koji se, uz finansijsku podršku Ministarstva prosvete i nauke RS, sprovodi na Odseku za srpsku književnost Filozofskog fakulteta u Novom Sadu.

1 Džejms Bejli (1929), profesor emeritus Univerziteta u Viskonsinu - Medison. Skoro trideset godina, sve do penzionisanja 1995. godine, Džejms Bejli je predavao Ruski jezik, književnost, poetiku i folklor na Odseku za slavistiku ovoga univerziteta. Bio je šef pomenutog odseka, Studija ruskog područja i Folklornog programa. Objavio je brojne studije o ruskoj književnosti, poetici i folkloru, među kojima je i knjiga Three Russian Lyric
} 
zamisao sažimanja tumačenja pojedinih pojmova u celokupnim njegovim radovima o stihu. Činjenica da je korespondencija pokrenuta 1994. godine, a da su spisi o stihu napisani i saopšteni osamdesetih godina ide u prilog ideji dopune, proširenja opsega interesnog područja ili razmatranja neukazanog aspekta određenog problema. Pritom, treba imati u vidu da je bitan faktor nadogradnje spektra značenja posebnih pojava svakako i razmena iskustva, koja pruža nova saznanja. Našavši da je susret sa dragocenim raspravama o zasebnim pitanjima u pismima podsticajan za osvrt na postojeća, ranije izrečena, zapažanja o istom, mišljenja smo da bismo time verovatno nagovestili integralno obličje opservacije svakog pojma i omogućili njihovu kompletnu karakterizaciju.

Među prvim pokrenutim temama za razgovor tako se našlo i pitanje opkoračenja, ${ }^{2}$ motivisano upravo separatom koji je Petrović kolegi poklonio. Istovetno interesovanje dvojice kolega rezultiralo je gotovo osmomesečnom (od januara do avgusta 1997. godine) diskusijom o kompleksnom terminu. S obzirom na obimnost razmatranja i zaključaka u pismima, kao i na mnoštvo izdvojenih zapažanja $\mathrm{i}$ raznih gledišta $\mathrm{o}$ anžambmanu $\mathrm{u}$ Petrovićevim radovima, $\mathrm{u}$ nemogućnosti smo da ih $\mathrm{u}$ jednom tekstu obuhvatimo, te za drugu priliku ostavljamo priređivanje prepiske, poštujući time i žanrovsku specifičnost i hronologiju, a čineći joj time ujedno i propedeutički tekst.

O opkoračenju kao pesničkom postupku, metričkoj pojavi „koja učestvuje u cjelovitoj ritmičkoj slici stiha jednog pjesnika" (2003b: 234), pisao je Petrović u više navrata, što je u korelaciji sa zastupljenošću ovog termina u problematizovanju određenih tema: očekivano je da u kompendiju o stihu, uz preciziranje naziva pojava, bude koncizno ukazano i na njihovo značenje, jer se reči u opkoračenju i prebacivanju posebno ističu. ${ }^{3}$ Isto tako, u knjizi o problemu soneta, najvećoj oblasti njegovog interesovanja, data je samo kratka beleška, premda ona sadrži pregršt važnih informacija o istorijatu napuštanja utvrđenog strofnog sonetnog okvira,

Folk Song Meters (1993). Preveo je i priredio, zajedno sa Tatjanom Ivanovom, An Anthology of Russian Folk Epics (1998).

${ }^{2}$ Pojavu razbijanja sintaksičke celine prenošenjem nekoliko reči u novi stih, odnosno situaciju u kojoj je ona ,započeta u jednom, a dovršena tek u idućem stihu zovemo opkoračenjem (franc. enjambement; dolaze u nas i nazivi: prekoračenje i zakoračenje)" (Petrović, 1983: 370).

${ }^{3}$ Ove su pojave, stoga, karakteristične ,za naglašeno nervozno, napeto saopćavanje, puno sumnje ili bola, [...]; ono također veoma često služe, osobito u dramskoj poeziji, kao sredstvo da se stihu nametne razgovorna, prozna intonacija” (Petrović, 1983: 371). 
odnosno o opkoračenju dveju sonetnih celina, koje će u određenom književnom periodu signalizovati pesničku invenciju. ${ }^{4} \mathrm{U}$ ponekom radu o stihu zaseban segment posvećen je opkoračenju, kojim se argumentuju književnoistorijska situacija i efekti semantika stiha; međutim, problematici opkoračenja posvećena su i dva celovita rada.

\section{O ODNOSU SINTAKSIČKIH I STIHOVNIH GRANICA}

„Prva je pretpostavka valjanog razgovora o odnosu sintaktičkih i stihovnih granica razumijevanje da su to dvije vrste granica u pjesničkom govoru", intendira naše istraživanje Petrović ovim opštim zapažanjem u kontekstu rasprave o dvanaesteračkoj tužbalici (2003f: 412): ${ }^{5}$

Stih i nije ništa drugo nego uvodjenje u govorni niz jedne segmentacije koja sa stanovišta svakodnevnog jezika nije 'prirodna', i sama pomisao da bi se stihovno moglo bolje opisati ako bi se najprije normaliziralo po kriterijima izvedenim iz opisa svakodnevnog jezika u potpunoj je suprotnosti sa onim što stihovno bitno jest. Jasno je samo po sebi da sintaktička segmentacija ne može biti osnova za utvrđivanje šta je stih u slučajevima u kojima je razlaz stihovne i sintaktičke segmentacije značajna crta stihovanja (npr. u versifikaciji u kojoj je prošireno opkoračenje). Ali nije u načelu drugačije ni u versifikaciji u kojoj postoji težnja da se sintaktičke i stihovne granice podudaraju. To podudaranje, naime, nikad se ne može shvatiti kao potpuno podudaranje - sa stihovnim granicama neke jačine podudaraju se sintaktičke granice različitih jačina, i obrnuto - pa je ono zapravo prvenstveno zabrana za neke vrste izrazitog nepodudaranja (2003f: 412).

U svetlu tog međuodnosa, koji je u osnovi našeg uobičajenog shvatanja opkoračenja, a od kojeg i sam polazi, treba poimati svako izlaganje na tu temu.

2.1. U radu koji se čini polazišnim, „Opkoračenje u srpskohrvatskom stihu: postojana podloga" (2003b: 231-246), ${ }^{6}$ Petrović ukazuje na to da tu uobičajenu koncepciju opkoračenja kao „vrste odnosa među metričkim i sintaktičkim

\footnotetext{
${ }^{4}$ Videti: Petrović, 2003g: 118.

5 Tekst „Postoji li, uistinu, tročlani dvanaesterac?” prvobitno je objavljen u časopisu Umjetnost riječi, XXIX, 1985, 3, 273-300.

${ }^{6}$ Izvorno pod naslovom „Enjambement in Serbo-Croatian: A Stable Background”, u: Slavic Linguistics and Poetics. Studies for Edward Stankiewicz on his $60^{\text {th }}$ Birthday, 17 November 1980 (IJSLP XXV/XXVI, 1982), 355-366. Srpskohrvatski prevod u: Godišnjak XI Odjeljenja za književnost Instituta za jezik i književnost u Sarajevu, 1982, 9-20. U daljem tekstu, kada citiramo delove rada o kojem je reč, navodimo samo brojeve stranica.
} 
osobinama" (243) ne treba brkati sa pojmom opkoračenja koji upotrebljavaju i koji su razvili Milman Peri (Milman Parry) i Albert Bejts Lord (Albert Bates Lord), ${ }^{7}$ a koji ne samo što se razlikuje od uobičajenog, jer je drugačije zamišljen, nego je zadobio i širi smisao, pre svega radi potreba komparativnog proučavanja usmenog epa. ${ }^{8}$ Ideja nužnog opkoračenja (necessary enjambement) i neperiodičnog opkoračenja (unperiodic enjambement) u njihovoj koncepciji rasvetljava problem koji se prvenstveno odnosi na parataktičko i hipotaktičko vezivanje stihova, a ne samo na stihovni i sintaksički međuodnos.

Da bi definicija opkoračenja u uobičajenom smislu bila kompletna, ona „bi morala da implicira jasno razumijevanje funkcije opkoračenja, a zapravo i funkcije stiha" (243). Pritom, na osnovu poznate stare definicije M. Gramona (M. Grammont), ${ }^{9}$ Petrović ukazuje na nedostatke popularnih definicija. Izdvaja tumačenje Viktora Žirmunskog, za kog je najkarakterističnija osobina opkoračenja upravo „sintaktička pauza unutar stiha koja je jača od pauze na početku ili kraju istog stiha", te markira njegovo objašnjenje da se prisutnost opkoračenja

${ }^{7}$ O ovim profesorima, klasičnim filolozima, videti: Petrović, 2008a: 177-180. Tekst je prvobitno objavljen u Letopisu Matice srpske, 1991, 167, knj. 447, sv. 3, 516-519.

${ }^{8} \mathrm{O}$ tome je pisao još 1969 . godine u radu „Poredbeno proučavanje srpskohrvatskoga epskog deseterca i sporna pitanja njegovoga opisa", objavljenom prvobitno u Zborniku Matice srpske za književnost i jezik, XVII, 173-203. Konstatuje da se pitanje stiha u savremenom poredbenom proučavanju epskog pesništva ,pojavilo samo sasvim marginalno u istraživanjima što ih je izazvala poznata teorija o tehnici usmenoga pravljenja stihova $\mathrm{M}$. Perija, razvijena osobito njegovim učenikom A. Lordom, teorija koja je na studij Homera i srednjovjekovnoga epa na Zapadu u toku poslednjih nekoliko decenija utjecala odlučnije nego ma koje drugo pojedinačno gledište”. Ukazuje se na to da je ta teorija „, najvećoj meri osnovana na tipološkoj usporedbi Homera i srpskohrvatskog epskog pjesništva" (173) i da je njihov istraživački interes bio usmeren na proučavanje upotrebe anžambmana u Homera i u srpskohrvatskom epu, tumačenjem razlike „među dvjema tradicijama u upotrebi tzv. nužnog anžambmana okolnošću da je heksametar gipkiji a epski deseterac 'the shorter and stricter...versse”" (209). Upućuje na rad A. B. Lorda „Homer and Huso III: Enjambement in Greek and Southslavic Heroic Song", TAPhA 79, 1948, 113-124. Videti: Petrović, 2003a: $165-216$.

9 „M. Grammont: 'Quand une proposition, commencée dans un vers, se termine dans le suivant sans le remplir tout entier, on dit qu'il y a enjambement' (Petit Traité de versification française, Paris, 1908, str. 20)" (243).

„Kada se jedna rečenica, započeta u jednom stihu, završava u narednom tako da ga ne ispunjava čitavog, kažemo da postoji opkoračenje" (Mali traktat o francuskoj versifikaciji). Za potrebe ovog rada prevela Sonja Veselinović. 
„uspostavlja prvenstveno odnosom među sintaktičkom granicom unutar stiha i onom na njegovom kraju, a ne apsolutnom važnošću neke sintaktičke pauze same po sebi” (243).

Ne prihvatajući premisu da je opkoračenje inovacija srpskog i hrvatskog pesništva 20. veka, kako je istaknuto u radovima opštih opisa srpskohrvatske versifikacije (tačnije u delima Kirila Taranovskog i Svetozara Matića), Petrović će, motivisan tom nepreciznošću, uvideti potrebu za sažetim opštim opisom koji može da posluži jednom studioznom prikazu istorijskog razvoja i upotrebe opkoračenja $u$ srpskohrvatskom pisanom stihu. Razmatranja $\mathrm{u}$ ovom tekstu vid su pripreme za problematizovanje pitanja pojave opkoračenja u usmenom narodnom stihu, o čemu će kasnije nastati zaseban rad. Hronološki se u radu ukazuje na promenljiv položaj opkoračenja u našem stihu, od srednjovekovne literature sve do početka 20. veka, čime se skreće pažnja na proširenost i poznavanje ovog postupka i pre moderne, kako su to do tada navodili u svojim pregledima istoričari i teoretičari književnosti.

Uz napomenu da u pobožnim pesmama, koje se pevaju ili stilizovano kazuju, ne očekujemo čestu pojavu opkoračenja, Petrović njegovo potpuno odsustvo iz takvog pesništva, koje, kako kaže, ,jasno udara u oči”, dovodi u sumnju, posebno uzimajući u obzir to da je opkoračenje i te kako prisutno u poeziji koja je bila uzor našoj srednjovekovnoj. U tom kontekstu porekao je pretpostavku Đorđa Trifunovića da opkoračenje nije u duhu i u skladu sa načelom vizantijske metrike, kojoj je ,stih uvek logičko-sintaksička celina” (1990: 335), ${ }^{10}$ podvlačeći podatak o obilnoj upotrebi opkoračenja u vizantijskoj učenoj poeziji, koje je ,posredovano slavenskoj pismenosti u tekstu koji predstavlja možda prve prave stihove napisane jednim slavenskim jezikom: šest opkoračenja [(...)] nalazimo u nešto više od sto stihova Konstantinova Proglasa svetog jevanđelja" (244).

Već sa našom renesansnom i baroknom poezijom opkoračenje postaje „proširena metrička konvencija”, te ga pesnici u dvostruko rimovanom dvanaestercu, dominantnom dužem stihu tog perioda, koriste bez ograničenja i na različite načine. Javlja se i u ondašnjem glavnom kraćem stihu, simetričnom osmercu, ali ne jednako kroz čitav period; najizrazitije u drugoj polovini 16. i na početku 17. veka. Posebno je važno izdvojiti njegovo zapažanje ,da se doba krize dvanaesterca u ulozi glavnog,

${ }^{10}$ Videti odrednicu STIHOVI u Azbučniku srpskih srednjovekovnih književnih pojmova, 1990: 333-339. U takvim se stihovima, prema tome, razabira Trifunović, ,ne može pojaviti opkoračenja”, pa su „tim svojim načelom stari srpski stihovi veoma bliski prirodi stiha narodne, usmene poezije (osmerca, deseterca i dr.), gde vrlo retko nalazimo opkoračenje" (335). 
gotovo jedinog stiha ozbiljne poezije, i njegove zamjene u toj ulozi simetričnim osmercem, podudara sa vremenom naglašene upotrebe opkoračenja u osmeračkim stihovima svih značajnijih pjesnika, od S. Bobaljevića do I. Gundulića" (244). Istovremeno, izrazita naklonjenost ovom postupku prisutna je i u Evropi, a za njen glavni izvor smatrala se italijanska poezija tog doba, sa kojom je opkoračenje viđeno „kao sredstvo koje služi nekoj temeljnijoj pjesničkoj svrsi” (233), poput odraza stanja duha, ili kao osobina pesnikovog stila.

Tokom 17. veka jenjava plima opkoračenja; retko je i u narednom veku, da bi početak 19. veka doneo novi talas upotrebe opkoračenja, koje Petrović razvrstava na manirističko i klasicističko. Prvim se, izdvajajući Jovana Pačića, koji ga najbolje predstavlja, osim odnosa prema toj poeziji, impliciraju „sve one upotrebe opkoračenja u kojima se neposredno iskazuje i njegova stilska funkcija i njegova povezanost sa nemetričkim postupcima koji teže istoj svrsi” (234). Njemu oponira druga vrsta, u kojoj je opkoračenje, pojašnjeno na primeru pesništva Lukijana Mušickog, „prvenstveno sastavni dio metričkog sloja, koji stilski funkcionira samo posredno, tj. u mjeri u kojoj učestvuje u oblikovanju metričkog sloja a taj se, uz to, pokazuje kao stilski značajan" (235). Dakle, zaključuje o distinkciji Petrović, dok manirističko opkoračenje nije vezano za neku posebnu vrstu stihova, klasicističko je, naprotiv, ograničeno samo na srpske ekvivalente klasičnih oblika, u cilju isticanja jedne pesničke tradicije, dok se u stihovima druge vrste pažljivo izbegavalo.

Već se četrdesetih godina 19. veka ublažava upotreba opkoračenja, da bi se sa srpskim romantizmom, u narednim decenijama istog veka, tronizovala versifikacija koja održava poklapanje sintaksičke i metričke granice, tj. ne trpi opkoračenje, kako formuliše Petrović. I upravo u tom periodu, kada kod nas nastupa novi književni jezik i kanonizuje se usmena narodna književnost, koju karakteriše stil dodavanja ${ }^{11}$ iliti zabrana opkoračenja, razilazimo se, iz pomenutih razloga, sa evropskom istorijom opkoračenja, u kojoj je ono „bilo cijenjena tekovina romantičkog pokreta i jasan znak romantizma" (237). Ukazivanje na različitu poziciju, upotrebu i označenost opkoračenja u našem stihu u odnosu na stihove evropskih jezika prepoznaće Petrović kao intenciju skrivenu u osnovi tih nepreciznih formulacija opštih opisa versifikacije. Dakle, osobit položaj opkoračenja u srpskohrvatskom stihu u direktnoj je relaciji sa značajem usmene narodne tradicije u toj književnosti.

Kada se i javljalo opkoračenje kod nekih pesnika, ono se najčešće smatralo „pogreškom, ropskom imitacijom stranih uzora ili jednostavno metričkom nespretnošću” (238), što jeste ,rezultat dosljedne primjene jednoga tradicionalnog

${ }^{11} \mathrm{O}$ ovom terminu vidi dalje u tekstu. 
gledišta" (236), kakvo zastupa S. Matić. Ukazaće tom prilikom Petrović i na strogu uslovljenost Matićevog stanovišta o opkoračenju kao pesničkoj inovaciji sa početka 20. veka (v. 238-239).

„Opkoračenje, naravno, uvijek podrazumeva kao svoju podlogu stih bez opkoračenja”, zaključuje Petrović, podrazumevajući kao postojanu podlogu narodni stih (239). Dakle, pokazatelj odnosa prema narodnoj pesničkoj tradiciji jesu obe situacije, zapaža on, tj. i upotreba i izbegavanje opkoračenja; biranje alternativne tradicije, koja prihvata opkoračenje, uvek podrazumeva tradiciju iz koje je ono odsutno. Ukazujući na postojanje mnoštva različitih efekata opkoračenja, što zavisi od konkretne pojave, pridodaće mu i ,sposobnost da na vrlo specifičan način komentira odnos pjesme prema tradiciji” (239), što je u velikom delu 19. veka „najvažnija njegova ekspresivna upotreba na srpskohrvatskom” (240), premda se ona može neutralizovati, odnosno prigušiti ukoliko se pažnja usmeri ka retoričkim, stilističkim ili muzičkim efektima, „u slučaju pojedinačnog napadnog opkoračenja u kontekstu koji opkoračenje inače ne poznaje, i u slučaju poezije koja opkoračenje prihvaća kao prirodno nasljeđe iz prošlosti” (240).

2.2. Poredeći repertoare pesničkih oblika u srpskom i hrvatskom romantizmu sa onim u evropskom romantizmu, Petrović (2003c: 280-287) ${ }^{12}$ izvodi dva zapažanja, izdvajajući kao primer, pored pitanja koje se tiče međunarodnog repertoara stalnih oblika strofe i pesme, pitanje opkoračenja, ,tj. pitanja o odnosu versifikacije u kojoj se sintaktička i stihovna segmentacija razilaze i versifikacije u kojoj takav razlaz nije dozvoljen, što znači osobine koja na bitan način utječe na stih jednog jezika" (281282). U ovom se tekstu samo osvrće na prethodni rad, u celini posvećen ovom problemu, te daje samo koncizne konstatacije za potrebe poredbenog pristupa, koje ukazuju na izneverena očekivanja: ,[...], opkoračenje se često koristi i u srpskoj i u hrvatskoj poeziji kraja 18. i početkom 19. vijeka, i opet javlja na obje strane potkraj 19. vijeka, ali je na vrlo izrazit način odsutno iz poezije koju nazivamo romantičkom, sa izuzetkom nekih od najranijih tekstova, o kojima smo, međutim, u svojoj stilskoj karakterizaciji ionako često neodlučni” (282). U periodu tokom kog je opkoračenje u evropskom romantizmu cenjena tekovina i njegov jasan znak, kako ističe Petrović, $u$ srpskohrvatskoj literaturi potpuno je suprotna situacija, tumačena njenim specifičnim odnosom domaćeg i stranog, tj. „kanonizacijom usmenih narodnih pjesničkih uzora $\mathrm{u}$

${ }^{12} \mathrm{Za}$ tekst izvorno pod naslovom „Poetic Forms in Serbian and Croatian Romanticism” autor napominje da je objavljen u internom zborniku Xenia Miroslao Červenka quinquagenario a sodalibus, amicis, discipulis oblata, Pragae MCMLXXXII, u jednom primerku, u vlasništvu Miroslava Červenke (287). 
pisanoj književnosti” (284). „Opkoračenje se, udomaćen stari postupak pisane poezije na srpskohrvatskom, odbacivalo”, zaključuje on, „zato što je stoljećima u ovoj tradiciji bilo takođe znak stava - negativnog stava - prema usmenom narodnom pjesništvu" (286).

2.3. I u radovima o semantici stiha ponoviće istu tvrdnju. Tekstom „Semantika srpskog i hrvatskog stiha u drugoj polovini devetnaestog vijeka” (2003d: 288-327 $)^{13}$ markiraće očekivane semantičke efekte stiha, vidljive na dvema ravnima: stilističkoj ${ }^{14}$ i poetičkoj. ${ }^{15} \mathrm{U}$ kontekstu vremena temom obuhvaćenog ukazaće na, u našoj poeziji, retku upotrebu opkoračenja i kršenja cezure kao stilističkih sredstava, jer se, pretpostavlja on, u srpskohrvatskoj tradiciji njima distancira od usmene narodne poezije, ukazujući pritom na objedinjenost efekata obeju ravni (308-310).

Ponovnim osvrtom na semantičke efekte stiha, u radu „Stilistika versifikacionih postupaka Zmajevih" (2003e: 328-350), ${ }^{16}$ ovde sada klasifikovane, po ravnima pesničkog dela, na stilističke, retoričke i poetičke, ${ }^{17}$ te tvrdnjom o njihovoj ravnopravnosti i uslovljenosti, tj. njihovom međuodnosu, istaknutom $u$ prethodnom radu, Petrović ukazuje na dominantnost stilističkih efekata u Zmajevom pesništvu i daje tročlanu klasifikaciju njegovog repertoara versifikacionih postupaka, utemeljenu u teoriji Jiržija Levija (Jiří Levý) ${ }^{18}$ o trima osnovnim vrstama efekata, izvedenim „iz tri osnovna principa organizacije teksta na fizičkoj ravni” (v. 332-334). Kao sredstva prve grupe navodi intonaciono-ritmičke postupke, ,različite upotrebe granica sintaktičkih i stihovnih, i njihova medjuodnosa, skup postupaka, dakle, u kojemu se naročitom izrazitošću izdvajaju kršenje cezure i opkoračenje, s različitom čestoćom u različitim razdobljima i stilskim orijentacijama - vrlo često, na primjer, u romantizmu i razmjerno rijetko u klasicizmu - javljaju se u istoj ulozi" (334). Ovi postupci, koje u stilističkoj ulozi u poeziji najčešće srećemo, u Zmajevom stihu, kao i kod većine njegovih savremenika, jesu, suprotno očekivanju, ograničeni. Štaviše, u tadašnjem

${ }^{13}$ Osnovne ideje rada izložene su na konferencijama u Varšavi 1981. i 1983. godine. Tekst je objavljen i u zborniku Slowiańska metryka porównawcza III. Semantyka form wierszowych, Wroclaw, etc, 1988, 164-188.

${ }^{14}$ Efekti „koje utvrđujemo tumačenjem odstupanja od uspostavljenog stihovnog obrasca pjesme" (308).

${ }^{15}$ Efekti „,koje utvrđujemo pitajući se o specifičnoj aktuelizaciji, ako ne neutralizaciji, onog značenja koje je stih stekao ranijim upotrebama u pjesničkoj tradiciji” (308).

${ }^{16}$ Prvobitno objavljen u zborniku Zmajev stih, Novi Sad, 1985, 173-191.

${ }^{17}$ Autor potvrđuje da je opštu koncepciju književnog dela (jedinstvo dimenzija pisca, teksta i čitaoca, odnosno ravni poetičke, stilističke i retoričke) primenio na oblast stiha (329).

${ }^{18}$ O ovom češkom teoretičaru književnosti vidi: Petrović, 2008b: 293-296. 
periodu u srpskoj i hrvatskoj poeziji dolazi do jačanja silabičko-tonskog stiha, koji je, podvlači Petrović, dobra podloga postupcima ove grupe (338). Međutim, da bi ukazao na to šta je u osnovi potiranja važnosti postupaka ove grupe, akcentuje sponu stilističke i poetičke oblasti u semantici stiha i ističe da se jedino kroz njihovo istovremeno razumevanje može objasniti manja uloga opkoračenja kod Zmaja i neiskorišćenost svih njegovih formalnih mogućnosti. Polazi se, naime, od metametričke označenosti opkoračenja u srpskoj poeziji toga vremena jer se ono uvek sagledava i kao pokazatelj „odnosa prema nacionalnoj pjesničkoj tradiciji”, u ovom slučaju prvenstveno kao „znak odstupanja od tradicije usmenoga narodnog pjesništva", za koju se Zmaj opredelio (347). ${ }^{19}$

Opkoračenje kod Zmaja istraživači su različito tumačili; neki su negirali prisustvo, a pojedini ga uočavali svuda, posebno u pesmama za decu. No Petrović ipak tvrdi, potkrepljujući to primerima, da se pravo opkoračenje, definisano kao „razlaz stihovne i sintaktičke segmentacije teksta u kome je neka sintaktička granica unutar stiha izrazito jača od granice na njegovom kraju", kod Zmaja nalazi dovoljno često (340). Ovom tvrdnjom on ne poriče tačnost zaključaka starijih istraživača o odsustvu opkoračenja kod Zmaja; štaviše, Petrović markira i podržava razloge takvog stava jer su, osim sklonosti „da naše pjesništvo druge polovine 19. vijeka vide bližim normi narodnog stiha no što je ono uistinu bilo, [...] dobro zapažali neka važna ograničenja u Zmajevoj upotrebi opkoračenja, koja dozvoljavaju da se i samo postojanje opkoračenja u Zmajevoj poeziji dovede u pitanje" (340). Ukazuje pritom na to da se kod njega, u pravilu, opkoračuju dva kraća stiha, i to gotovo uvek povezana u paru, a veoma retko time vezuju dva duža stiha, što ga vodi zaključku ,da posla i nemamo s opkoračenjem nego s dužim stihovima - šesnaestercem, poljskim trinaestercem, četrnaestercem itd. - grafički razlomljenim na polustihove", potkrepljenom činjenicom ,da se i inače u Zmajevim pjesmama kratkog stiha dvostih, više nego pojedinačan stih, ponaša kao prava najmanja jedinica stihovnog niza" (341). Upravo ovakva konstatacija iznedriće relevantno zapažanje koje zasebno može da bude podsticajno za problematizovanje, a koje i sam autor uviđa kao zamršeno, teorijski zanimljivo, bez jednostavnih i nedvosmislenih rešenja: „grafički oblik pjesme nije ipak nešto što se može jednostavno zanemariti, a ni dokidanje opkoračenja samovoljnim zahvatima u izvorni grafički oblik ne može posve ukloniti onaj razlaz sintaktičke i metričke segmentacije koji se u opkoračenju izražavao" (341).

${ }^{19}$ Čak i u situaciji u kojoj je taj postupak podesan, ističe Petrović, Zmaj ga nije smatrao najprikladnijim jer nije u skladu sa srpskim običajem. Videti napomenu 9, 349-350. 
2.4. Iako nagovešteno u svim pomenutim prethodnim radovima, pitanje prisutnosti opkoračenja u usmenoj poeziji zasebno se razmatra u tekstu „Opkoračenje u srpskohrvatskom usmenom stihu" (1988: 139-168), a, kako autor sam ističe, najviše je podstaknuto zapažanjima Edvarda Stankijeviča (Edward Stankiewicz) ${ }^{20}$ koja oponiraju prethodnim stručnim mišljenjima o odsustvu opkoračenja u narodnom stihu, odnosno mišljenjima „u kojima se i izuzetna pojava opkoračenja u usmenom stihu smatra spornom" (146).

Ponovo se polazi od razlike u definiciji, pa čak i u ideji opkoračenja kakvu su utemeljili Peri i Lord u odnosu na uobičajeno značenje te reči i podvlači ranije navedeno određenje tog pojma, adekvatno raspravi o pesništvu (v. tekst o Zmaju). Takva formulacija će, prema njegovom mišljenju, i dobro nagovestiti „da ono što obično prepoznajemo kao opkoračenje nije zaseban, diskretan stihovni postupak nego naročit, vrlo jak slučaj nečega što možemo smatrati i prirodnim stanjem stihovanog govora", jer potpuno podudaranje dveju vrsta granica više je izuzetna nego najobičnija pojava, napominje Petrović, potkrepljujući to navedenim opštim zapažanjima u radu o tročlanom dvanaestercu (141). Isti opis značenja opkoračenja, ukazuje on, bio je validan i u najvažnijim ranijim tumačenjima naše narodne metrike, pa se i zbog toga može smatrati zadovoljavajućim, što je pregledno predstavio kroz karakterizaciju narodnog stiha Toma Maretića, ${ }^{21}$ Svetozara Matića ${ }^{22}$ i Romana Jakobsona. $^{23}$

Opšti sud istraživača usmene narodne versifikacije je da ,naš narodni stih u načelu zabranjuje opkoračenje" (146), ali isto tako svi navode da su moguća retka odstupanja od tog stihovnog pravila $\mathrm{i}$ po tome se, $\mathrm{u}$ proceni o njenom broju $\mathrm{i}$

${ }^{20}$ Videti prepisku S. Petrovića sa ovim slovenskim lingvistom, profesorom na Jejlu, 2015: 145-194. U istoj knjizi prepiske sa strancima nalazi se i zanimljiv podatak o recepciji ovoga Petrovićevog rada. Naime, Norman V. Ingam (Norman W. Ingham), profesor slovenskih jezika i ruske književnosti na Univerzitetu u Čikagu, maja 1990. zahvaljuje Petroviću na prijemu ovoga teksta o opkoračenju: ,[...] nalazim da je interesantan, pogotovo zbog definicije i poetskog potencijala prekoračenja usmenog stiha" (2015: 58).

${ }^{21}$ Njegovi rezultati su mu mogli poslužiti u ovoj raspravi „pogotovo zato što je Maretić dobro shvatao da je opkoračenje samo rijedak krajnji oblik onoga ponašanja govora u stihu koje je inače, dok ne prijeđe neku granicu, zapravo više ili manje obično" (143).

22 Posebno izdvaja Matićevo važno zapažanje o funkciji anadiploze (ponavljanja polustihova u narednom stihu) u očuvanju stiha kao zasebne sintaksičke celine, tj. sredstva kojim se izbegava opkoračenje.

23 Petrović izdvaja Jakobsonov opis opkoračenja novim pojmovnim jezikom u dvema prilikama, u studijama iz tridesetih i pedesetih godina. 
karakteru, međusobno i razlikuju u opisima. Razlika u mišljenjima uslovljena je i obimom prihvaćene definicije opkoračenja, kao i karakterom građe, podseća Petrović. Povrh svih proučavanja narodne metrike, kako tradicionalnih tako i modernih, jasno je, ističe on, da se isključuje mogućnost da opkoračenje u usmenom pesništvu bude izrazita i česta pojava, kakva je u pisanom pesništvu. To će potkrepiti i analizom neadekvatne rekonstrukcije narodne pesme po starom zapisu.

I prema pojedinačnim pojavama opkoračenja odnosili su se proučavaoci kritično i sumnjičavo, te su pribegavali drugačijem načinu čitanja, kojim bi se ono izbeglo ,zato što remeti neku cjelovitu predstavu o prirodi usmenog narodnog stiha" (157). U tom kontekstu Petrović se posebno osvrće na načine kojima Novica Petković poriče opkoračenje, među kojima privlači pažnju skandiranje stihova, ${ }^{24}$ odnosno prioritetnost stihovne jedinice i intonacionog zahteva nad sintaksičkim (156). Razmatranje udela rečenične intonacije u raspravi o stihu dovešće ga do zaključka da „kao postupak u otkrivanju i provjeravanju pojave opkoračenja u pjesmi, proučavanje intonacije nema, ukratko, samostalne vrijednosti” (158), naprotiv, njime se možemo baviti tek kada ustanovimo opkoračenje. Međutim, da način čitanja usmenog stiha, tj.skandiranje, ne mora delovati nasilno, Petrović opravdava tehnikom građenja narodne pesme opisanom u studijama Perija i Lorda. ${ }^{25}$ Tako se, tvrdi on, pojava opkoračenja u usmenom pesništvu i naša nesigurnost u identifikaciji istog najbolje shvataju ,ako se ogledaju u svijetlu” (160) te tehnike, tačnije postupka dodavanja, nizanja stihova, prelaza iz stiha u stih.

Dakle, tvrdi se da ,je opkoračenje predvidljivo rijetko u pjesništvu u kome su bilo stih bilo polustih ujedno i sintaktičke jedinice nekog reda, a dominantni je princip građenja složene rečenice parataksa”, kao i da je „najvažnija specifična formalna osobina opkoračenja u usmenom stihu: okolnost da rejet u njemu uvijek ide samo do cezure i ispunjava čitav prvi polustih (odnosno, kad je u pitanju contrerejet, da uvijek počinje tek na cezuri i ispunjava čitav drugi polustih), mada je u tom

\footnotetext{
${ }^{24}$, „[...]: da se tekst pjesme, bez ikakvih ustupaka zahtjevima sintakse i smisla (i prirodnog naglašavanja riječi slučaju stiha silabičko-tonskog), čita doslovno onako kako nas upućuje njegova stihovna organizacija" (159).

${ }^{25}$ Petrović navodi Perijev termin stil dodavanja, nazivan i neperiodičkim opkoračenjem, u značenju načina na koji se raščlanjuje rečenica na stihove u usmenoj epskoj poeziji: „misao se zapravo dovršila na kraju stiha, a u idućem se stihu odnosno stihovima samo slobodno dodaju nove ideje kojima se iskaz dopunjuje ili razrađuje" (159).
} 
stihu inače poznato i opkoračenje cezure" ${ }^{\text {26 }}$ (160), što znači samo onda kada je polustih jedinica nizanja. I u toj okolnosti poklapanja sintaksičkog odmora sa bar jednim metričkim odmorom (sa cezurom i krajem stiha) krije se, po njegovom mišljenju, razlog naše nesigurnosti u određivanju opkoračenja u narodnoj pesmi, posebno što je znamo samo po zapisu, za razliku od „čovjeka žive usmene tradicije, kojemu već način pjevanja ili kazivanja razgovjetno utuvljuje neprikosnoven primat granice na kraju stiha" (160).

Samim tim, ukoliko postoji jaka semantička povezanost polustihova u stihu režea, opkoračenje može da se osujeti, što potvrđuje primerom iz Ženidbe Maksima Crnojevića (,a ja, braćo, jesam govorio / na prosidbi, kad snahu isprosih,”). A upravo takva, „latentna opkoračenja, u kojima se efekat opkoračenja može neutralizirati ako jaka semantička veza sintaktički razdvojenih polustihova neutralizira sintaktičku granicu na cezuri, u našem su usmenom pjesništvu znatno češća od pravih opkoračenja" (161), što dokazuje i primerima stihova precizirajući njihov semantički potencijal (oznaka mesta i njegovo imenovanje; događaj i njegovo objašnjenje; uzrok i posledica). Mogu se skandirati i stihovi sa pravim opkoračenjem, čime se podvlači višeznačnost koju u pesmi opkoračenje proizvodi, smatra Petrović, što ne znači da se time ono neutralizuje, nego se ističu njegove mogućnosti uspostavljanja „koegzistencije različitih značenja” (162).

Rasprava o naravi pojave opkoračenja, kako je sam determiniše, nastavlja se konstatacijom neočekivanosti njegove ekspresivne uloge, a time i nezadobijanja statusa stihovnog postupka u usmenom pesništvu, što se argumentuje okolnošću odsustva iz našeg usmenog stiha one upotrebe opkoračenja koja bi se najviše očekivala kada bi ono imalo funkciju stihovnog postupka, a misli se na upotrebu „koja odlučnu prevlast paratakse koristi da bi se opkoračenjem proizveo jak efekat obrta i iznenađenja, što praktički znači jak humoristički, ironijski, parodijski, u prostodušnijim vrstama pjesništva najobičnije lascivni efekat" (164).

\section{ZAKLJUČAK}

Sameravanjem svih viđenja i prikaza upotrebe opkoračenja u Petrovićevim spisima, pre svega se temeljno definiše pojam i sagledava u odnosu na postojeće

\footnotetext{
${ }^{26}$ Francuski termin rejet koristimo da označimo prebacivanje, tj. prenošenje pojedinačne reči u drugi stih; „nekad i kao opis za pojedinačnu riječ koja opkoračuje granicu polustiha običnije se to zove rejet à l'hémistiche - ali nekad i općenitije, kao naziv za onaj dio sintaktičke cjeline koji se u opkoračenju našao u drugom stihu" (Petrović, 1983: 370).
} 
definicije; pritom se pravi razlika između uobičajenog smisla (prihvatljivog u praktičnoj primeni većini onih koji se bave pesništvom) i proširenog obima pojma (recipročnog građi na kojoj se izučava opkoračenje; primera radi, pri kompariranju usmenih epova poželjan je uvid šireg smisla pojma koji podrazumeva i samo sintaksičke odnose unutar stiha). Sveobuhvatnost razumevanja pojave, po Petrovićevom mišljenju, implicira ne samo identifikaciju nepoklapanja dveju granica nego i funkciju, kako opkoračenja tako i stiha, što se razrešava od slučaja do slučaja. Tako uviđamo da postoje različite vrste opkoračenja, koje mogu indicirati kakva mu je stilska funkcija, tj. da li je u pitanju ekspresivna upotreba, nemetrički motivisana, ili govorimo o postupku uzglobljenom sa metričkim slojem, tj. posredno stilski obeleženom. Kao što je pojava raznovrsna, tako postoje i različiti aspekti njenog tumačenja, a isto tako i različite njene svrhe, bilo da zadire $u$ domen pesničke slobode i metričkih odlika, bilo da ima neku konkretnu namenu. Činjenica je da sama pojava može da ukazuje na načine čitanja stihova usmeravajući nas na značenje koje pesnik želi da postigne.

$\mathrm{Uz}$ pregled literature relevantne za razumevanje ovog postupka i pregnantnih fusnota/beležaka, kojima se umnožava perspektiva van nacionalnog okvira, nadasve su sugestivne polemike sa dosadašnjim shvatanjima i tumačenjima, posebno, s jedne strane, po pitanju preciziranja istorijskog razvoja, jer se njegovim analizama pomeraju granice prisustva opkoračenja u vremenu i vrsti lirike, a $\mathrm{s}$ druge strane, po pitanju prisustva opkoračenja u usmenom narodnom stihu. Naime, može se zaključiti da je položaj opkoračenja uslovljen aktuelnom tradicijom pojedine književnosti; da se njegovom upotrebom, tačnije i prisustvom i odsustvom, razotkriva odnos prema pesničkoj tradiciji, što govori o zadobijenoj metametričkoj označenosti. A upravo su razlike u mišljenjima izučavalaca narodne metrike uslovljene pomenutim opsegom prihvaćene definicije. Činjenica je da se opkoračenje u usmenom stihu retko javlja, ali i nesigurnost pri identifikaciji te izuzetne pojave podstaknuta je specifičnom tehnikom građenja narodne pesme, koju Peri i Lord nazivaju stilom dodavanja ili neperiodičkim opkoračenjem, kao i okolnošću da je jedinica nizanja u usmenom pesništvu polustih, pri dominaciji parataktičkog građenja rečenice. Bez obzira na načine izbegavanja opkoračenja kako bi se zadovoljila tradicija usmenog pesništva, kakav je, recimo, skandiranje stihova, ne može se zanemariti to da je ova pojava u skladu sa ,prirodnim stanjem stihovanog govora", te da se iz te perspektive njeno odsustvo uviđa kao neočekivano. 
Sanja J. Paripović Krčmar

\section{OBSERVATIONS ON ENJAMBMENT IN WRITINGS ON A VERSE BY SVETOZAR PETROVIĆ}

\section{Summary}

By examining all the views and depictions of the use of enjambment in Petrović's writings, the term is thoroughly defined and perceived as being relative to existing definitions, thus differentiating between the usual sense and the extended scope of the term. There are different types of enjambment that can indicate its stylistic function: whether it is a nonmetrically motivated expressive use or if is it a process coupled with a metric layer, (i.e. indirectly stylistically marked). There are different aspects of its interpretation, and likewise can have different purposes: whether it enters the domain of poetic freedom and metric characteristics or it has some specific purpose. The very appearance of this figure of speech can indicate the ways verses should be read, thus directing us to the meaning the poet wanted to achieve. Petrović is polemic with previous understandings and interpretations, in particular regarding the issues of specifying historical development and the presence of enjambment in oral folk verse.

Key words: Svetozar Petrović, enjambement, syntactic and metric segmentation, Parry and Lord, semantic effects of the verse, oral folk verse

\section{LITERATURA}

Gikić Petrović, R. (prir.) (2015). Prepiska Svetozara Petrovića sa strancima. Novi Sad - Akademska knjiga - Fondacija „Legat Svetozara Petrovića”.

Petrović, S. (1983). Stih. U: Škreb, Z., Stamać A. Uvod u književnost - Teorija, metodologija. 3. prerađeno izdanje. Zagreb: Grafički zavod Hrvatske, 365428.

Petrović, S. (1988). Opkoračenje u srpskohrvatskom usmenom stihu. U: Petrović, S. (ured.) (1988). Usmeno i pisano/pismeno u književnosti i kulturi. Colloquia Litteraria, Naučni skupovi, knj. IV. Novi Sad: VANU, 139-168. (štampano ćirilicom)

Petrović, S. (2003a). Poredbeno proučavanje srpskohrvatskoga epskog deseterca i sporna pitanja njegovoga opisa. Oblik i smisao - Spisi o stihu. Beograd: Fabrika knjiga, 165-216. (štampano ćirilicom)

Petrović, S. (2003b). Opkoračenje u srpskohrvatskom stihu: postojana podloga. Oblik i smisao - Spisi o stihu. Beograd: Fabrika knjiga, 231-246. (štampano ćirilicom) 
Petrović, S. (2003c). Pjesnički oblici u srpskom i hrvatskom romantizmu. Oblik $i$ smisao - Spisi o stihu. Beograd: Fabrika knjiga, 280-287. (štampano ćirilicom)

Petrović, S. (2003d). Semantika srpskog i hrvatskog stiha u drugoj polovini devetnaestog vijeka. Oblik i smisao - Spisi o stihu. Beograd: Fabrika knjiga, 288-327. (štampano ćirilicom)

Petrović, S. (2003e). Stilistika versifikacionih postupaka Zmajevih. Oblik i smisaoSpisi o stihu. Beograd: Fabrika knjiga, 328-350. (štampano ćirilicom)

Petrović, S. (2003f). Postoji li, uistinu, tročlani dvanaesterac? Oblik i smisao - Spisi o stihu. Beograd: Fabrika knjiga, 383-430. (štampano ćirilicom)

Petrović, S. (2003g). Problem soneta u starijoj hrvatskoj književnosti - (Oblik $i$ smisao). Beograd: Samizdat $\mathrm{B}_{92}$.

Petrović, S. (2008a). Albert Bejts Lord. Pojmovi i čitanja. Beograd: Fabrika knjiga, $177-180$.

Petrović, S. (2008b). In memoriam: Jiří Levý (1926-1967). Pojmovi i čitanja. Beograd: Fabrika knjiga, 293-296.

Trifunović, Đ. (1990). Azbučnik srpskih srednjovekovnih književnih pojmova, drugo, dopunjeno izdanje. Beograd - Nolit. (štampano ćirilicom) 